\title{
Preparation and in vivo evaluation of glyco-gold nanoparticles carrying synthetic mycobacterial hexaarabinofuranoside
}

\author{
Gennady L. Burygin ${ }^{*} 1,2$, Polina I. Abronina ${ }^{3}$, Nikita M. Podvalnyy ${ }^{3}$, \\ Sergey A. Staroverov ${ }^{1}$, Leonid O. Kononov ${ }^{3,4}$ and Lev A. Dykman ${ }^{1}$
}

\author{
Full Research Paper \\ Address: \\ ${ }^{1}$ Laboratory of Immunochemistry, Institute of Biochemistry and \\ Physiology of Plants and Microorganisms, Russian Academy of \\ Sciences, Prospekt Entuziastov 13, Saratov, 410049, Russia, \\ ${ }^{2}$ Department of Horticulture, Breeding, and Genetics, Vavilov Saratov \\ State Agrarian University, Teatralnaya Ploshchad 1, Saratov, 410012, \\ Russia, ${ }^{3}$ Laboratory of Carbohydrate Chemistry, N.D. Zelinsky \\ Institute of Organic Chemistry, Russian Academy of Sciences, \\ Leninsky prospekt 47, Moscow, 119991, Russia and ${ }^{4}$ Phystech \\ School of Biological and Medical Physics, Moscow Institute of Physics \\ and Technology (National Research University), Institutsky per. 9, \\ Dolgoprudnyi, Moscow Region, 141701, Russia \\ Email: \\ Gennady L. Burygin* - burygingl@gmail.com \\ * Corresponding author \\ Keywords: \\ conjugation of glycosides; gold nanoparticles; lipoarabinomannan; \\ Mycobacterium; spacer aglycon \\ Beilstein J. Nanotechnol. 2020, 11, 480-493. \\ doi:10.3762/bjnano.11.39 \\ Received: 09 December 2019 \\ Accepted: 20 February 2020 \\ Published: 19 March 2020 \\ Associate Editor: J. Lahann \\ (C) 2020 Burygin et al.; licensee Beilstein-Institut. \\ License and terms: see end of document.
}

\begin{abstract}
A number of bacterial glycans are specific markers for the detection and the serological identification of microorganisms and are also widely used as antigenic components of vaccines. The use of gold nanoparticles as carriers for glyco-epitopes is becoming an important alternative to the traditional conjugation with proteins and synthetic polymers. In this study, we aimed to prepare and evaluate in vivo glyco-gold nanoparticles (glyco-GNPs) bearing the terminal-branched hexaarabinofuranoside fragment (Ara ${ }_{6}$ ) of arabinan domains of lipoarabinomannan and arabinogalactan, which are principal polysaccharides of the cell wall of Mycobacterium tuberculosis, the causative agent of tuberculosis. In particular, we were interested whether the antibodies generated against Ara $_{6}$-GNPs would recognize the natural saccharides on the cell surface of different mycobacterial strains. Two synthetic Ara 6 glycosides with amino-functionalized spacer aglycons differing in length and hydrophilicity were directly conjugated with spherical gold nanoparticles $(d=15 \mathrm{~nm})$ to give two sets of glyco-GNPs, which were used for the immunization of rabbits. Dot assays revealed cross-reactions between the two obtained antisera with the hexaarabinofuranoside and the 2-aminoethyl aglycon used for the preparation of glyco-GNPs. Both antisera contained high titers of antibodies specific for Mycobacteria as shown by enzyme-
\end{abstract}


linked immunosorbent assay using $M$. bovis and M. smegmatis cells as antigens while there was only a weak response to $M$. phlei cells and no interaction with $E$. coli cells. The results obtained suggest that glyco-GNPs are promising agents for the generation of anti-mycobacterial antibodies.

\section{Introduction}

A number of bacterial glycans $[1,2]$ are specific markers for the detection and the serological identification of microorganisms [3-5] and are widely used as antigenic components of vaccines [6-23]. The use of gold nanoparticles (GNPs) [24-26] as carriers for glyco-epitopes is becoming an important alternative [15,27$48]$ to the traditional conjugation with proteins, synthetic polymers and other carriers $[15,17,38,49-55]$. Immunological properties of GNPs [25,56,57] and their use in vaccine development [58] have recently been reviewed. Glyco-gold nanoparticles (glyco-GNPs) bearing residues of tumor-associated monosaccharide Tn [37] or disaccharide Thomsen-Friedenreich (TF) [35] antigens, a tetrasaccharide of the Streptococcus pneumonia type-14 capsular polysaccharide [33,34,47], or lipopolysaccharides of Burkolderia mallei [42] have been shown to be promising vaccine candidates.

Tuberculosis (TB), which is caused by the pathogenic bacterial species Mycobacterium tuberculosis, remains one of the ten most common causes of death worldwide. Nearly two million people die from the disease every year [59-63]. Although M. $t u$ berculosis has been extensively studied [64], TB presents an ever-growing challenge, and novel strategies for the prevention and treatment of TB are urgently needed [59]. Lipoarabinomannan (LAM) and the related arabinogalactan (AG) are two major structural components of the M. tuberculosis cell wall. Previous studies revealed that LAM and especially its terminal oligosaccharide fragments, conjugated with proteins $[7,10,19]$ or monophosphoryl lipid A [23], are attractive targets for the development of carbohydrate-based anti-TB vaccines $[7,10,19,23,65,66]$.

In this study, we aimed to prepare and evaluate in vivo glycoGNPs bearing the terminal-branched hexaarabinofuranoside fragment (Ara 6 , Figure 1), which is common for the arabinan domains of both LAM and AG and has earlier been identified as one of the lead structures $[7,10,65]$. Specifically, we were interested whether the antibodies generated against Ara $_{6}$-GNPs would recognize the natural saccharides on the cell surface of different mycobacterial strains.

For the preparation of glyco-GNPs, glycans are usually transformed to glycosides with thiol-functionalized spacer aglycons that are conjugated $[43,44]$ either with pre-formed citrate-stabilized GNPs [67] or during the in situ synthesis of glyco-GNPs $[32,38,46]$. It is also possible to conjugate suitably derivatized

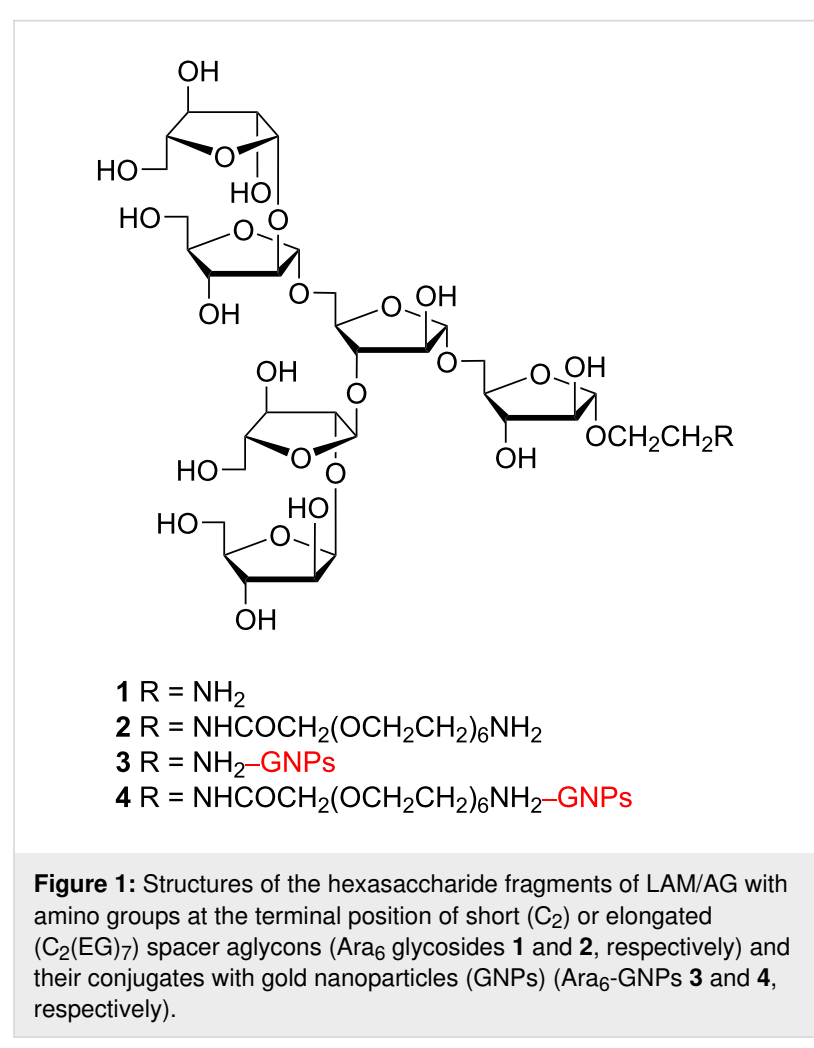

glycans [48] via additional functional groups of thiol-functionalized ligands attached to the surface of pre-formed GNPs.

We, however, chose an alternative approach that relies on the direct conjugation of amino-functionalized Ara 6 glycosides with pre-formed citrate-stabilized GNPs that possess no additional ligands. The use of amine-terminated ligands for binding with GNPs is well established [68-71] although not very popular with glycans yet. Indeed, the direct conjugation of amino-functionalized antigenic glycans with pre-formed GNPs has not been reported yet, to the best of our knowledge. This is despite the fact that simple amines, amino acids and peptides [68-78], as well as diethylaminoethyl-dextran [79] and chitosan [80] have been reported to bind to GNPs in a pH-dependent manner as the energy of the $\mathrm{Au}-\mathrm{N}$ interaction is intermediate between those of $\mathrm{Au}-\mathrm{S}$ and $\mathrm{Au}-\mathrm{O}$ [81]. The affinity of different functional groups to the surface of GNPs decreases in the series $\mathrm{Au}-\mathrm{S}>\mathrm{Au}-\mathrm{NH}_{2}>\mathrm{Au}-\mathrm{COOH}$ [82], which enables the exchange of citrate ligands with amines. The amine-capped GNPs are stable enough to be used as targeting agents for drugdelivery applications [75], as antigens for the generation of anti- 
bodies [77], or as antimicrobial agents [78]. These nanoconjugates are nontoxic, effectively penetrate into the cells and can be used as carriers [83]. It has been demonstrated that the amine-gold surface interaction is charge-neutral and the stability of amine-capped GNPs is a finite-size effect, which is largely kinetic in origin, unlike that of thiol-capped GNPs, which are known to possess thermodynamic stability with respect to the desorption of capping ligands and subsequent particle aggregation [68].

The nature and the length of the spacer aglycon are known to affect the presentation of carbohydrate ligands [84-90]. This, in turn, determines the molecular recognition of glycan moieties including those incorporated in glyco-GNPs [38,40,91]. In order to find out whether such an influence would be critical for the immunization with $\mathrm{Ara}_{6}$-GNPs and specificities of the elicited antibodies, two synthetic Ara 6 glycosides with aminofunctionalized spacer aglycons differing in length and hydrophilicity $\left(\mathrm{Ara}_{6} \mathrm{C}_{2} \mathrm{NH}_{2}\right.$ (1) and $\mathrm{Ara}_{6} \mathrm{C}_{2} \mathrm{EG}_{7} \mathrm{NH}_{2}$ (2) $[92,93]$, Figure 1) were conjugated with gold nanoparticles $(d=15 \mathrm{~nm})$ $[67,94]$ to give two sets of Ara $_{6}$-GNPs (3 and 4, respectively). The latter were used for the generation of antibodies that were then characterized by dot assay and enzyme-linked immunosorbent assay (ELISA), which confirmed their specificity against Mycobacteria.

\section{Results}

\section{Preparation and characterization of conjugates of amino-functionalized glycosides with GNPs \\ Glycans}

The known hexasaccharide fragments of LAM/AG with amino groups at the terminal position of short $\left(\mathrm{C}_{2}\right)$ or elongated $\left(\mathrm{C}_{2} \mathrm{EG}_{7}\right)$ spacer aglycons (Ara 6 glycosides $\mathbf{1}$ and $\mathbf{2}$, respectively, Figure 1) were prepared as described previously [92,93] and used without any further modification for direct conjugation with pre-formed GNPs.

\section{Glyco-GNPs}

In order to prepare the glyco-GNPs, Ara 6 glycosides 1 and 2 (Figure 1) were directly conjugated to pre-formed [67,94] freshly prepared citrate-stabilized spherical gold nanoparticles ( $d=15 \mathrm{~nm}$, identical to those prepared earlier [77]) to give the corresponding Ara 6 -GNPs 3 and 4 (Figure 1), which have the same size as the parent GNPs according to transmission electron microscopy (TEM) (Figure 2).

According to the colorimetric determination of carbohydrates (phenol-sulfuric acid reaction, see the Experimental section for details) in the samples of glyco-GNPs 3 and $\mathbf{4}$, which were puri-
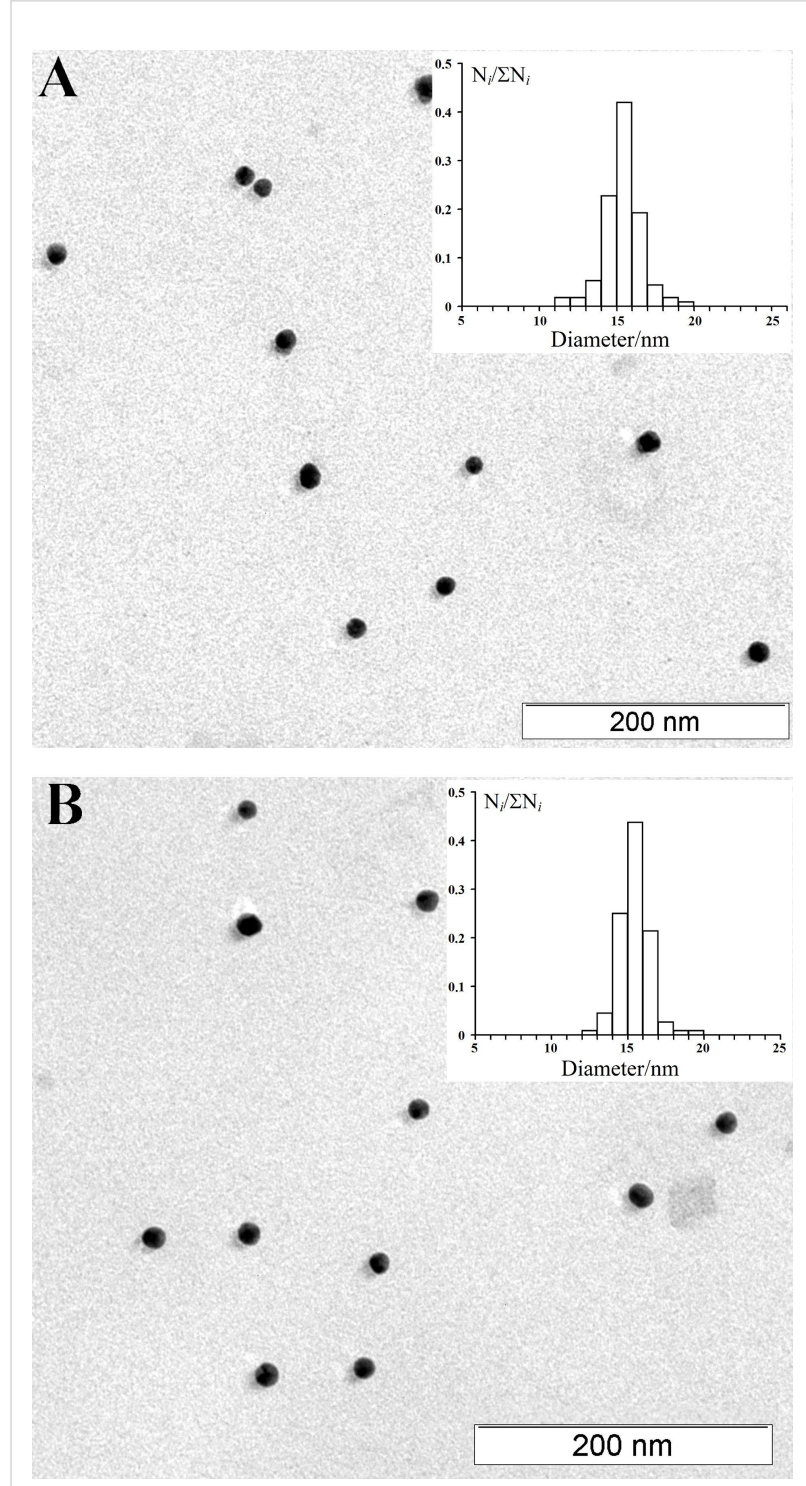

Figure 2: Transmission electron microscopy (TEM) images of $\mathrm{Ara}_{6}{ }^{-}$ GNPs $3(A)$ and $4(B)$. The insets show size distribution diagrams with $15 \mathrm{~nm}$ average diameter in both cases.

fied from the excess of $\mathrm{Ara}_{6}$ glycosides $\mathbf{1}$ and $\mathbf{2}$ by centrifugation, there are no more than 100 glycoside molecules on each nanoparticle on average.

Spherical citrate-stabilized GNPs with $15 \mathrm{~nm}$ average diameter (which are often considered as standard GNPs for immunochemical studies due to ease of preparation and conjugation with ligands $[48,56,57]$ and have successfully been used in our previous studies $[56,57,77,78,95])$ were chosen for the experiments. This is because GNPs of this size, unlike much smaller GNPs (e.g., around $2 \mathrm{~nm}$ in diameter), which are often derivatized in situ $[32,39,46,48]$, can be easily prepared in advance and kept for further conjugation with a desired ligand. Another 
advantage of using these GNPs is their strong light absorption due to localized surface plasmon resonance (LSPR) around $520 \mathrm{~nm}$ while colloids of GNPs smaller than $3 \mathrm{~nm}$ do not exhibit an LSPR and are barely colored. It is known that the color of GNP colloids dramatically depends on size and shape of the GNPs as well as on the dielectric properties of the medium surrounding the GNPs. These features are useful in many (bio)analytical applications including monitoring their stability (as described below) $[25,26,46]$. Size and shape of the GNPs (spheres, nanorods, nanoshells and nanostars) were shown to influence the immunogenicity of conjugates with haptens. Large spherical GNPs ( $d=15$ and $50 \mathrm{~nm})$ are the optimal antigen carriers and adjuvants for immunization [96].

Nature and length of the spacers (linkers) have been selected to modulate the stability of the $\mathrm{Ara}_{6}$-GNPs, as well as to control the presentation of the $\mathrm{Ara}_{6}$ hexasaccharide epitope on the surface of the GNPs in order to explore the effect of a linker on the immunogenicity. The very short $\mathrm{C}_{2}$ linker (only two aliphatic carbon atoms) of glycoside $\mathbf{1}$ was chosen to allow the $\mathrm{Ara}_{6}$ hexasaccharide moiety to protrude just a little above the shell of $\mathrm{Ara}_{6} \mathrm{C}_{2} \mathrm{NH}_{2}$-GNPs 3. This makes the recognition of the glycan epitope potentially problematic (for this reason, such short linkers are not popular in neoglycoconjugate chemistry). Thus, glyco-GNPs 3 were initially planned to serve as negative control. The Ara 6 hexasaccharide was also conjugated to a much longer and flexible hydrophilic linker based on heptaethylene glycol $\left(\mathrm{EG}_{7}\right)$, which was initially expected to allow for a better recognition of the glycan epitope on the surface of $\mathrm{Ara}_{6} \mathrm{C}_{2} \mathrm{EG}_{7} \mathrm{NH}_{2}$-GNPs 4 than on the surface of $\mathrm{Ara}_{6} \mathrm{C}_{2} \mathrm{NH}_{2}-$ GNPs 3. The differences in hydrophilicity and rigidity of the spacers in glycosides $\mathbf{1}$ and $\mathbf{2}$ were also expected to affect the stability of the formed Ara $_{6}$-GNPs 3 and $\mathbf{4}$.

\section{Stability of glyco-GNPs}

Gold hydrosols are typical lyophobic colloids that are stable only under conditions of low ionic strength. Under physiological conditions, GNPs are thermodynamically unstable and require stabilization. The sol stability can be increased by coating the GNPs with a ligand layer. As a result, the particle surface acquires the properties of the stabilizing agent under use. These stabilized GNPs can be lyophilized and become much less sensitive to electrolyte-induced coagulation (due to electrostatic and hydrophobic interactions and structural-mechanical stability factors) $[57,97,98]$. The minimal stabilizing concentrations for both glycosides $\mathbf{1}$ and $\mathbf{2}$ were found to be $100 \mu \mathrm{g} \cdot \mathrm{mL}^{-1}$. This concentration was used to conjugate antigens 1 and 2 with GNPs, which gave glyco-GNPs 3 and 4 .

The TEM data of the prepared Ara $_{6}$-GNPs 3 and 4 (Figure 2) clearly suggest that coupling of the Ara 6 glycosides 1 and 2 with GNPs did not change the size of nanoparticles $(d=15 \mathrm{~nm})$ and that aggregation is absent. The addition of $\mathrm{NaCl}$ solution to conjugates of GNPs with Ara $_{6}$ glycosides 1 and 2 (Ara 6 -GNPs 3 and $\mathbf{4}$, respectively) allowed us to determine the differences in ability of $\mathrm{Ara}_{6}$ glycosides $\mathbf{1}$ and $\mathbf{2}$ to stabilize the GNPs at different $\mathrm{pH}$ values (Figure 3 ). The highest stabilizing ability was demonstrated by Ara $_{6}$ glycoside 1 with 2-aminoethyl spacer aglycon while $\mathrm{Ara}_{6}$ glycoside 2 with a longer spacer aglycon was slightly inferior and could stabilize GNPs only at $\mathrm{pH}$ values of 9.7 and above. For this reason, immunization of rabbits was carried out with solutions of Ara $_{6}$-GNPs 3 and 4 at $\mathrm{pH} \approx 9.7$, at which both Ara $_{6}$-GNPs 3 and 4 were stable in saline medium.

The stability of the prepared glyco-GNPs $\mathbf{3}$ and $\mathbf{4}$ against aggregation followed from the experiments with three different types
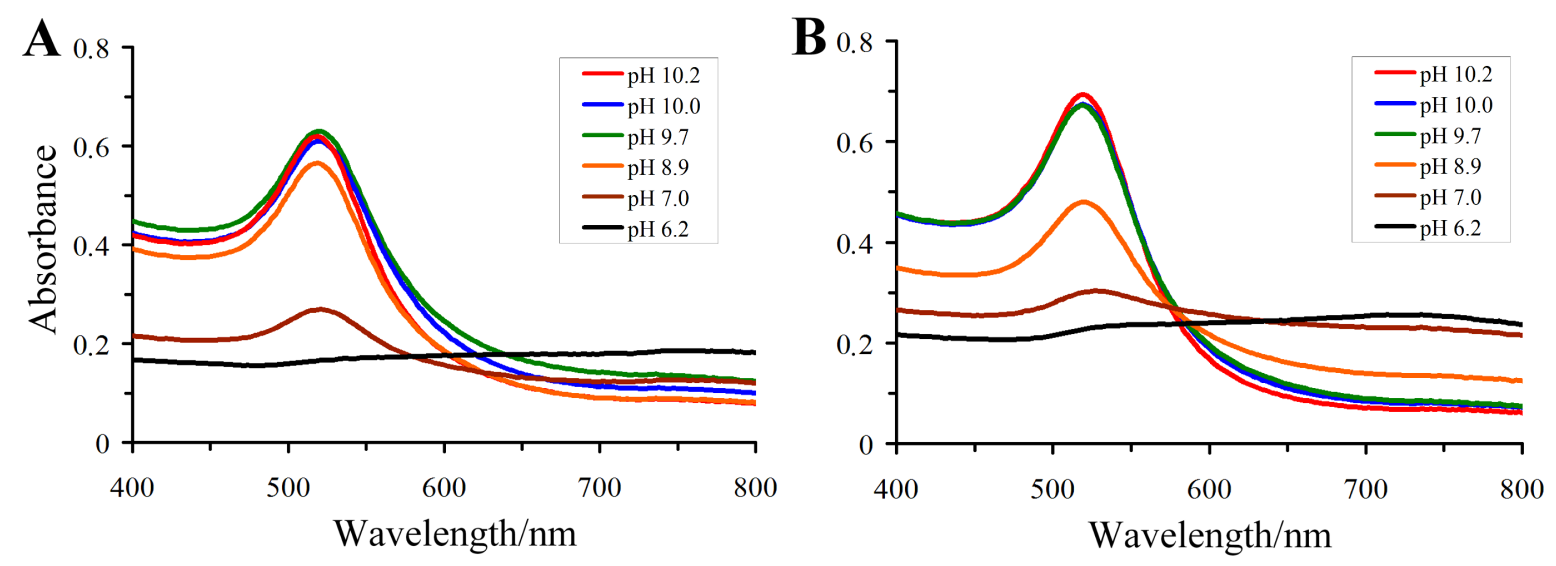

Figure 3: Absorption spectra of solutions of $\mathrm{Ara}_{6} \mathrm{C}_{2} \mathrm{NH}_{2}-\mathrm{GNPs}(3)(\mathrm{A})$ and $\mathrm{Ara}_{6} \mathrm{C}_{2} \mathrm{EG}_{7} \mathrm{NH}_{2}-\mathrm{GNPs}(4)$ (B), prepared from solutions of containing $100 \mu \mathrm{g} \cdot \mathrm{mL}^{-1}$ of glycosides and $0.9 \% \mathrm{NaCl}$, at different $\mathrm{pH}$ values. The glycan components in glyco-GNPs 3 and 4 are hexasaccharide fragments $\left(\mathrm{Ara}_{6}\right)$ of mycobacterial LAM/AG with amino groups at the terminal position of short $\left(\mathrm{C}_{2}\right)$ or elongated $\left(\mathrm{C}_{2} \mathrm{EG}_{7}\right)$ spacer aglycons $\left(\right.$ Ara ${ }_{6}$ glycosides 1 and 2, respectively; see Figure 1). 
of solutions of glyco-GNPs $\mathbf{3}$ and $\mathbf{4}$, which (1) contained an excess of $\mathrm{Ara}_{6}$ glycosides 1 and $\mathbf{2}(\mathrm{pH} \approx 9.7$; these solutions were used for immunization), (2) were prepared in water from glyco-GNPs 3 or $\mathbf{4}$, which were purified from the excess of Ara $_{6}$ glycosides $\mathbf{1}$ and $\mathbf{2}$ by centrifugation, or (3) were prepared in $0.9 \% \mathrm{NaCl}$ from glyco-GNPs $\mathbf{3}$ or $\mathbf{4}$, which were purified by centrifugation, dissolved in $5 \%$ sucrose solution and then lyophilized. The absorption spectra of these solutions were virtually identical and very similar to that of the starting GNPs (Figure 4).

\section{Detection of glycosides by obtained sera}

The glyco-GNPs $\mathbf{3}$ and $\mathbf{4}$ were used for the hyperimmunization of rabbits. The interaction of the obtained polyclonal rabbit antisera with the starting glycosides $\mathbf{1}$ and $\mathbf{2}$ was studied by dot assay on a polyvinylidene fluoride (PVDF) membrane (Figure 5). Ara 6 glycoside 1 (with a short spacer aglycon) was detected by antisera against both $\mathrm{Ara}_{6} \mathrm{C}_{2} \mathrm{NH}_{2}$-GNPs 3 and $\mathrm{Ara}_{6} \mathrm{C}_{2} \mathrm{EG}_{7} \mathrm{NH}_{2}$-GNPs 4. This means that there was a serological cross-reaction for the obtained antisera against Ara $_{6}$-GNPs 3 and 4. Remarkably, both antisera were equally effective in detecting $\mathrm{Ara}_{6} \mathrm{C}_{2} \mathrm{NH}_{2}$ (1) in amounts as low as $60 \mathrm{ng}$. This unequivocally proves that both antisera are specific for the $\mathrm{Ara}_{6}$ hexasaccharide epitope. Glycoside 2 (with a long spacer aglycon) could not be detected by the dot analysis with any of the obtained antisera.

\section{Interaction of the obtained sera with mycobacterial cells}

Interaction with the mycobacterial cells of three model cultures (M. bovis, M. phlei and M. smegmatis) has been demonstrated for both obtained antisera against Ara $_{6}$-GNPs 3 and 4 by ELISA (Figure 6, Supporting Information File 1, Figure S1). Both antisera detected $M$. phlei cells significantly weaker than $M$. bovis and $M$. smegmatis cells. Importantly, none of the antisera interacted with $E$. coli cells. Control experiments showed that the observed specificity of the antisera against Ara $_{6}$-GNPs 3 and 4 is due to the presence of the Ara 6 -epitope in Ara $_{6}$-GNPs 3 and 4. It is not related to the presence of background anti-mycobacterial antibodies in intact rabbit serum used for immunization or antibodies generated against heat-inactivated $M$. tuberculosis cells, which are present in complete Freund's adjuvant (CFA),
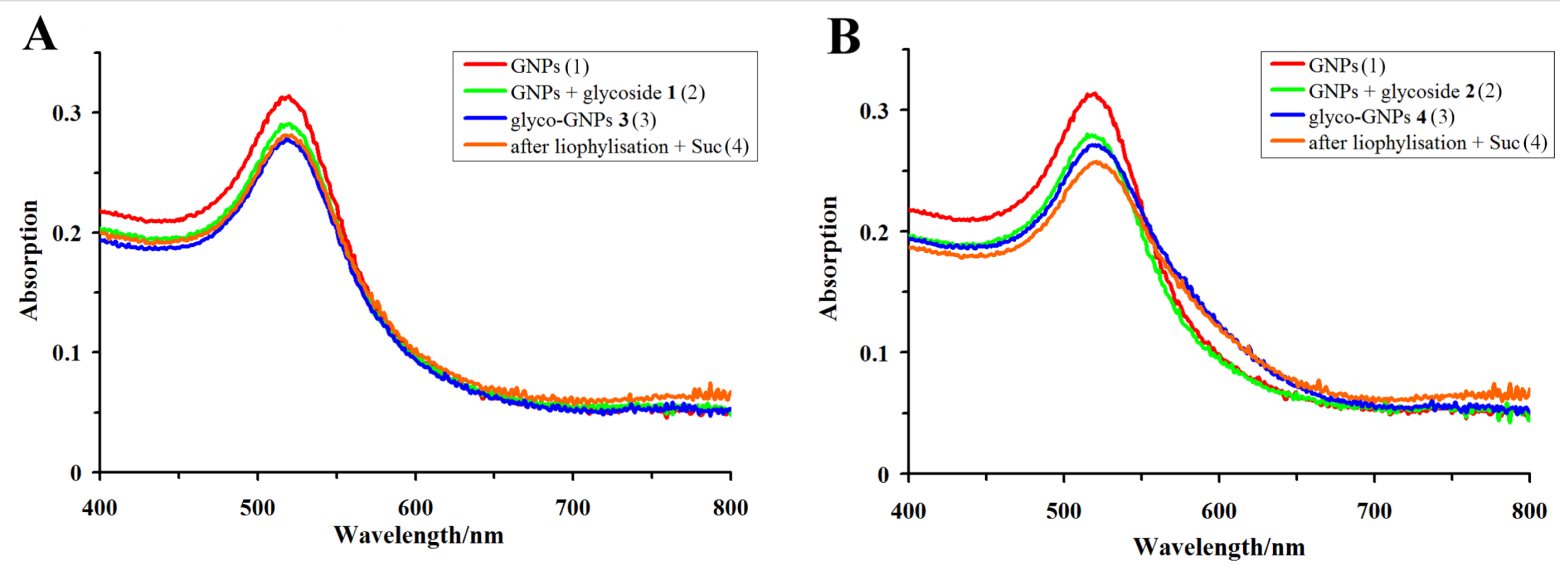

Figure 4: Spectra of (1) the solution of the starting GNPs prepared in water, (2) a mixture of solutions of GNPs (pH 9.7) and aqueous solutions containing $100 \mu \mathrm{g} \cdot \mathrm{mL}^{-1}$ of Ara 6 glycosides 1 (A) and 2 (B) (these mixtures were used for immunization; $0.9 \% \mathrm{NaCl}$ was additionally present in the samples of these mixtures used for recording the spectra), (3) solutions of glyco-GNPs $\mathbf{3}(\mathrm{A})$ and $\mathbf{4}$ (B) prepared in water from glyco-GNPs $\mathbf{3}$ or $\mathbf{4}$, which were purified from the excess of Ara 6 glycosides $\mathbf{1}$ and $\mathbf{2}$ by centrifugation of the mixtures of GNPs with glycoside solutions (see (2)), and (4) solutions of glyco-GNPs 3 (A) and 4 (B) prepared in $0.9 \%$ aqueous $\mathrm{NaCl}$ from glyco-GNPs $\mathbf{3}$ or $\mathbf{4}$, which were purified by centrifugation, dissolved in $5 \%$ sucrose (Suc) solution and then lyophilized.

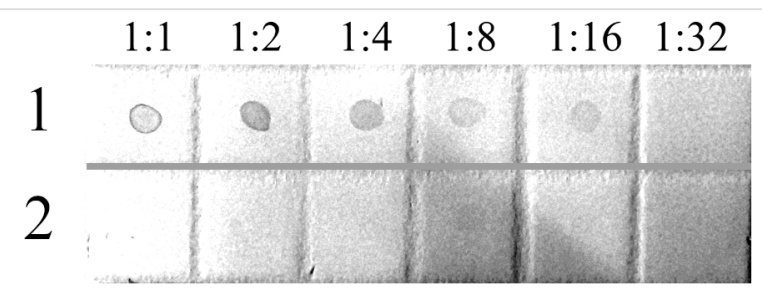

A

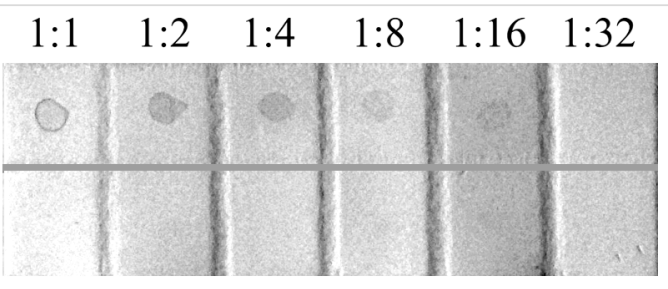

B

Figure 5: Results of the dot assay of Ara 6 glycosides 1 (1) and 2 (2) with antisera against $\mathrm{Ara}_{6} \mathrm{C}_{2} \mathrm{NH}_{2}-\mathrm{GNPs}_{(3)}(\mathrm{A})$ and $\mathrm{Ara}_{6} \mathrm{C}_{2} \mathrm{EG} \mathrm{G}_{7} \mathrm{NH}_{2}-\mathrm{GNPs}_{\mathrm{S}}(\mathbf{4})$ (B). Solutions of glycosides $\left(1 \mathrm{mg} \cdot \mathrm{mL}^{-1}\right)$ in $\mathrm{H}_{2} \mathrm{O}$ were titrated twice. 


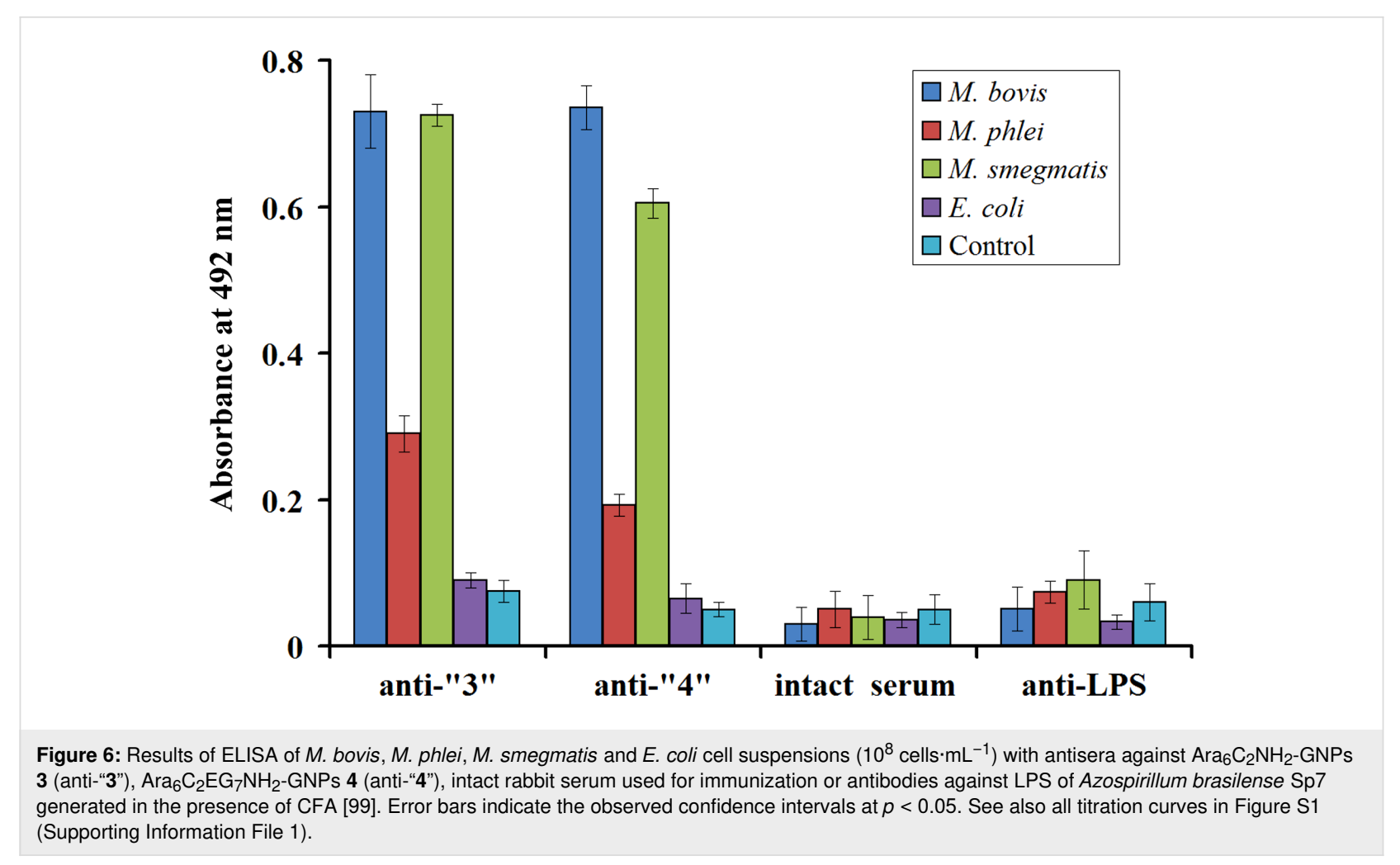

as no interaction of intact rabbit serum or antiserum against LPS of Azospirillum brasilense Sp7, generated in the presence of CFA [99], with M. bovis, M. phlei, M. smegmatis and E. coli cell suspensions could be detected (Figure 6).

\section{Discussion}

The biosynthesis of antibodies in mammals is induced by immunogenic substances. These compounds are typically characterized by a fairly developed structure and include proteins, polysaccharides, and a number of synthetic polymers. A significant part of biologically active substances, including glycosides, has a relatively small molecular mass. Low-molecular-mass antigens belong to the category of so-called weak antigens (haptens), i.e., a pronounced immune response against them is not developed (in general, substances with molecular mass ca $1 \mathrm{kDa}$ or less are not immunogenic). As a rule, haptens are conjugated with carrier proteins, such as bovine serum albumin, hemocyanin, ovalbumin, or thyroglobulin, to allow helper T-cell epitopes to stimulate an effective antibody response $[100,101]$. However, in this case antibodies are formed both against the hapten and against the immunodeterminant regions of the carrier. Moreover, the use of such a carrier does not ensure the development of a pronounced immune response against weak antigens. In addition, subsequent purification and screening of the resulting antibodies are laborious and expensive, and their titer and affinity are often low. When gold nanoparticles are used as both a carrier and adjuvant, high-titer anti- sera are obtained that do not require further purification from ballast antibodies [56,101].

In this study, hexasaccharide fragments of LAM/AG with amino groups at the terminal position of short $\left(\mathrm{C}_{2}\right)$ or elongated $\left(\mathrm{C}_{2} \mathrm{EG}_{7}\right)$ spacer aglycons ( $\mathrm{Ara}_{6}$ glycosides $\mathbf{1}$ and $\mathbf{2}$, respectively; Figure 1) were conjugated with pre-formed [67,94] gold nanoparticles $(d=15 \mathrm{~nm})$ to give the corresponding glycoGNPs with pendant $\mathrm{Ara}_{6}$ moieties $\left(\mathrm{Ara}_{6} \mathrm{C}_{2} \mathrm{NH}_{2}\right.$-GNPs (3) and $\mathrm{Ara}_{6} \mathrm{C}_{2} \mathrm{EG}_{7} \mathrm{NH}_{2}$-GNPs (4), respectively), which were found to be stable in the presence of $0.9 \% \mathrm{NaCl}$ only in alkaline media ( $\mathrm{pH} 8-10$, Figure 3). Noteworthy is the better stabilization of GNPs by Ara $_{6}$ glycoside 1 with a short 2-aminoethyl spacer aglycon.

It is important to stress that the removal of excess Ara 6 glycosides $\mathbf{1}$ and $\mathbf{2}$ from solutions of glyco-GNPs ( $\mathbf{3}$ and $\mathbf{4}$ ) or lyophilization of the purified glyco-GNPs $\mathbf{3}$ and $\mathbf{4}$ (provided that they were dissolved in 5\% sucrose solution prior to lyophilization) does not impair the stability of the prepared glyco-GNPs $\mathbf{3}$ and $\mathbf{4}$ against aggregation as follows from the similarity of the absorption spectra (Figure 4).

The prepared glyco-GNPs with pendant Ara 6 moieties (Ara6GNPs 3 and 4) were used for the immunization of rabbits. The alkalinity of the immunogen (conjugate of an antigen with GNPs) is typical for the immunization of animals, starting with 
the first published work on the production of antibodies using colloidal gold [102]. The prepared Ara 6 -GNPs 3 and $\mathbf{4}$ were not separated from the excess of ligands $\mathbf{1}$ and $\mathbf{2}$ and were used for hyperimmunization of rabbits without additional purification since it was reported that the presence of excess soluble antigen along with the same antigen immobilized on GNPs may be vital for inducing high levels of antibody response in immunization [98]. Although the role of the admixture of soluble antigen in inducing protective immunity is unclear yet [98], these results might suggest that leaching of antigen from the prepared glycoGNPs could be beneficial for the success of immunization while immunization with non-conjugated low-molecular-mass haptens $\mathbf{1}$ or $\mathbf{2}$ is not expected to induce any noticeable immune response (as noted above; see also the subsequent discussion on the putative mechanism of immunogenicity of glyco-GNPs). This also suggests that the increased stability of glyco-GNPs does not necessarily mean better immunization. Although one can argue that amine-linked carbohydrate ligands present in Ara $_{6}$-GNPs 3 and 4 might be exchanged with various thiols present in vivo, immunization with the prepared Ara $_{6}$-GNPs 3 and 4 was successful, which indicates that such glyco-GNPs preparations are indeed capable of inducing antibody response. Clarification of these complex issues clearly requires further studies.

The specificity of the obtained antisera against Ara $_{6}$-GNPs 3 and 4 was then studied. Dot assay, which is a traditional way for an initial rapid assessment of specificity of the antisera obtained, revealed cross-reactions for the two obtained antisera with the parent hexaarabinofuranoside 1 with 2 -aminoethyl aglycon (Figure 5). Therefore, antibodies in high titers of approximately the same specificity against the $\mathrm{Ara}_{6}$ hexasaccharide epitope are produced by immunization of rabbits with both Ara $_{6}$-GNPs 3 and 4. Of the two Ara 6 glycosides, only glycoside 1 with a short spacer aglycon can be used to detect specific antibodies by the dot assay. Lack of interaction between glycoside $\mathbf{2}$ and the obtained antisera in the dot assay is apparently related to the desorption of glycoside 2 with the much more hydrophilic spacer aglycon from the PVDF membrane during the assay. This explanation is further supported by the fact that it was impossible to use a nitrocellulose membrane for dot assay of the glycosides because of the higher hydrophilicity of this material than that of PVDF. For both glycosides 1 and $\mathbf{2}$, there was no adsorption to the nitrocellulose membrane, and as a consequence, no reaction with specific antisera (data not shown). The combination of these observations makes it possible to conclude that it is the $\mathrm{Ara}_{6}$ hexasaccharide epitope that determines specificities of both antisera.

Both antisera contained high titers of antibodies specific for Mycobacteria as shown by ELISA using M. bovis and M. smeg- matis cells as antigens. The antisera interacted weakly with $M$. phlei cells and there was no interaction with E. coli cells. Control experiments showed that the observed specificity of antisera against Ara $_{6}$-GNPs $\mathbf{3}$ and $\mathbf{4}$ is due to the presence of the Ara $_{6}$-epitope in Ara $_{6}$-GNPs $\mathbf{3}$ and $\mathbf{4}$ and is not related to the presence of background anti-mycobacterial antibodies, which could be present in intact rabbit serum used for immunization, or antibodies generated against heat-inactivated M. tuberculosis cells, which are present in CFA (Figure 6, Supporting Information File 1, Figure S1). The importance of using CFA for the generation of hapten-specific antibodies has been recently demonstrated [77]. The titers of antibodies against haptens amine-linked to GNPs decreased in the following order: (hapten + GNPs + CFA) $>$ (hapten + GNPs $) \gg($ hapten + CFA). No antibodies against GNPs have been detected in [77].

The results obtained suggest that glyco-GNPs bearing oligosaccharide fragments of mycobacterial LAM/AG are promising agents for the generation of anti-mycobacterial antibodies. The positive reaction of the obtained antibodies to the cells of all three mycobacterial cultures tested, in contrast to $E$. coli cells, confirms the antigenic identity of the $\mathrm{Ara}_{6}$ epitope and surface cell antigens for all Mycobacteria and the specificity for this group of bacteria. Nevertheless, we have identified differences in the interaction of antibodies, obtained with Ara 6 -GNPs, with the cells of three mycobacterial cultures by using the ELISA assay that may indicate a different presentation of LAM/AG on the surface of M. bovis/M. smegmatis cells and M. phlei cells. This observation suggests the possibility of serological individuality of M. phlei, despite the fact that M. smegmatis and $M$. phlei are phylogenetically close species. Both species belong to the group of "rapidly growing Mycobacteria", in contrast to $M$. bovis, which belongs to "slowly growing Mycobacteria" [103]. A serological cross-reaction between the M. bovis and M. smegmatis cells (in contrast to $M$. phlei cells) was previously noted for antibodies obtained against a tuberculin-GNPs conjugate [96].

Both sets of Ara $_{6}$-GNPs (3 and 4 ) that contained Ara $_{6}$ glycan epitopes with different spacer aglycons were equally effective in the generation of antibodies in rabbits. The fact that even $\mathrm{Ara}_{6} \mathrm{C}_{2} \mathrm{NH}_{2}$-GNPs (3) with a very short linker (only two carbon atoms) performed well is rather unexpected since it is commonly believed that a rather long spacer aglycon (more than five carbon atoms) is required for a correct recognition of glycan moieties and efficacious immunization $[38,40,46,91]$.

The observed differences in specificity of antibodies generated against the two sets of Ara $_{6}$-GNPs (3 and 4) suggest a substantially different presentation of the same glycan on the syn- 
thesized $\mathrm{Ara}_{6}$-GNPs 3 and 4. The antibodies against $\mathrm{Ara}_{6} \mathrm{C}_{2} \mathrm{EG}_{7} \mathrm{NH}_{2}$-GNPs 4 with the longer $\mathrm{C}_{2} \mathrm{EG}_{7}$ spacer aglycon are noticeably more selective towards different species of Mycobacteria. We hypothesize that this different presentation of the $\mathrm{Ara}_{6}$ epitope could include a different degree of clustering of glycans on the surface of the GNPs. $\mathrm{Ara}_{6} \mathrm{C}_{2} \mathrm{EG}_{7} \mathrm{NH}_{2}-$ GNPs 4 is apparently more dispersed over the surface of the GNPs and, hence, more accessible for interaction. These unusual features of the $\mathrm{Ara}_{6}$-GNPs conjugates could be related to differences in structures of the solutions [104] of the parent amino-functionalized $\mathrm{Ara}_{6}$ glycosides $\mathbf{1}$ and $\mathbf{2}$. We have recently argued [105-107] that the sometimes observed profound influence of the nature of the (functionalized) aglycon in a glycosyl acceptor may be related to the formation of reaction solutions with modified structures featuring different supramolecular assemblies of the reagents (supramers [104]) in solution. In a similar fashion, solutions of $\mathrm{Ara}_{6} \mathrm{C}_{2} \mathrm{NH}_{2}$-GNPs 3 with the shorter and more hydrophobic $\mathrm{C}_{2}$ spacer aglycon might form tighter [108-110] supramers in aqueous solution [104,111,112], which eventually would form more clustered Ara 6 -glycan domains on the surface of Ara 6 -GNPs. The results obtained clearly suggest that the choice of the spacer aglycon may be critical for the specificity of antibodies against the corresponding glyco-GNPs and the studies in this direction seem promising.

Glycoside 2 was previously used for conjugation with mycobacterial proteins for the serological detection of antibodies against $M$. tuberculosis [92]. It was shown that the conjugation of the recombinant proteins MPB-64 and Rv0934 with glycan 2 containing the $\mathrm{Ara}_{6}$ epitope increased the sensitivity of serodiagnosis by $10-15 \%$ as compared to the use of unmodified proteins. Here, instead of using protein carriers, conjugation of glycans with GNPs, which is experimentally much easier, was carried out. The obtained Ara 6 -GNPs 3 and $\mathbf{4}$ could potentially also be used for detecting antibodies against $M$. tuberculosis. We demonstrated the immunogenicity of Ara $_{6}$-GNPs, which opens the possibility of using similar glyco-GNPs in a new generation of vaccines aimed at preventing human and animal tuberculosis. Antibodies obtained against Ara $_{6}$-GNPs could also be used to detect Mycobacteria (serodiagnosis) and treat the diseases caused by them (passive immunity).

The generation of antibodies against carbohydrate antigens (epitopes) of Mycobacteria linked to GNPs has not been reported to the best of our knowledge. The successful use of glyco-GNPs as vaccines has been described by Parry and co-workers [37]. The authors observed that these nanomaterials generated a strong and long-lasting production of antibodies that are selective to the Tn-antigen glycan and crossreactive toward mucin proteins displaying Tn. Other authors
$[33,42,47]$ used glyco-GNPs to prepare specific antibodies against carbohydrate antigens or epitopes of the bacterial pathogens $S$. pneumonia and $B$. mallei in combination with peptides or proteins that activated the immune response. Safari et al. $[33,34]$ showed that the immunization of mice with glycoGNPs containing the tetrasaccharide epitope $S$. pneumonia type 14 without T-helper peptide did not result in the activation of the immune response of the animals (mice) or the production of specific antibodies.

The situation is rather complex as our analysis of the literature data on the use of thiol- and amino-containing glyco-GNPs suggests. It appears that the efficacy of antibody generation inversely correlates with the stability of the glycan-GNPs conjugates. The induction of a specific immune response (i.e., the generation of antibodies) against haptens is T-cell-dependent and requires the uptake (phagocytosis), processing and presentation of epitopes on MHC class-II molecules by antigenpresenting cells to the specific $\mathrm{T}$ cell. It remains unclear how this process can proceed with a hapten. At the moment, we cannot explain the mechanism of hapten release in immune cells. We speculate that phagocytosis of the antigen and the subsequent presentation of the epitopes on the surface of macrophages are important events in this positive regulation. According to the literature data, GNPs contribute to the penetration of antigens into phagocytic cells [56]. GNPs, in addition to their adjuvant properties, could lead to a more active uptake of glycans incorporated in glyco-GNPs since free glycans (haptens) cannot be phagocytosed per se due to their small size. Probably, the substitution of glycans on the surface of glyco-GNPs with endogenous cellular thiols and amines facilitates the subsequent translocation of glycans to the surface of macrophages, which is required for the activation of specific B-cells. Clearly, such a substitution is more favored for glyco-GNPs based on amine-terminated glycans than for the more stable glyco-GNPs based on thiol-terminated glycans (for B-cell activation, the latter require the addition of peptides/ proteins). A low-molecular-mass glycan (hapten) alone, i.e., without carrier, cannot induce a cellular immune response and a possible specific immune response induced by the unconjugated hapten would be minimal and hardly detected. Fallarini et al. [113] showed that the nanoconjugates are taken up by cells and that after the uptake the sugar moieties are detached from the gold surface to be presented on the surface of the cells. We believe that a similar mechanism is implemented in our case. Clearly, this theory requires further studies to support it.

Here, we demonstrated the successful use of glyco-GNPs bearing the hexasaccharide epitope of LAM/AG for the activation of a specific immune response against carbohydrate antigens in 
laboratory animals (rabbits). The results are helpful in the development of synthetic protein- and peptide-free glycoconjugate vaccines based on glyco-GNPs.

It should be noted that the interaction of functionalized GNPs with cells of the immune system is still far from being understood in detail and requires further studies [56]. Experiments aimed at elucidating the mechanisms of antibody production in response to the introduction of glyco-GNPs are planned in the near future.

\section{Conclusion}

The use of GNPs conjugated with glycoside $\mathbf{1}$ containing a terminal branched $\mathrm{Ara}_{6}$ hexasaccharide unit of mycobacterial LAM/AG with a short 2-aminoethyl spacer aglycon (glycoGNPs 3) was most effective in producing specific antibodies after immunizing rabbits. The antiserum obtained by hyperimmunization of rabbits with $\mathrm{Ara}_{6} \mathrm{C}_{2} \mathrm{NH}_{2}$-GNPs conjugate 3 allowed the detection of LAM/AG oligosaccharides $\mathbf{1}$ and $\mathbf{2}$ as well as cells of Mycobacteria with high titers.

The conjugate of GNPs with glycoside 2 containing the $\mathrm{Ara}_{6}$ hexasaccharide with a longer oligo(ethylene glycol) spacer aglycon (glyco-GNPs 4) showed a weak overall efficacy. In addition to the more complex synthesis of the glycoside $\mathbf{2}$, this glycoside is poorly absorbed on nitrocellulose and PVDF membranes, which significantly complicates the immunodetection of specific antibodies. In immunochemical tests, the obtained antibodies against $\mathrm{Ara}_{6} \mathrm{C}_{2} \mathrm{EG}_{7} \mathrm{NH}_{2}$-GNPs 4 did not yield better results than the antibodies against $\mathrm{Ara}_{6} \mathrm{C}_{2} \mathrm{NH}_{2}$-GNPs 3 containing the much simpler 2-aminoethyl spacer aglycon.

The results obtained clearly suggest that the choice of a linker between glycan and GNPs may be critical for the specificity of antibodies against the corresponding glyco-GNPs and the studies in this direction seem promising. The conjugates prepared in this study (Ara 6 -GNPs) are stable in water (after removal of excess Ara 6 glycoside by centrifugation) or in a saline medium (either at $\mathrm{pH} \geq 8.9$ or after lyophilization (in the presence of $5 \%$ sucrose) of the conjugate purified from excess Ara $_{6}$ glycoside). These features suggest that Ara 6 -GNPs (and other conjugates of GNPs with related glycans) might be useful for the immunochemical detection of antibodies against surface carbohydrate antigens of Mycobacteria.

In conclusion, glyco-GNPs containing fragments of LAM are promising agents for the activation of immunological reactions to Mycobacteria in humans and animals and generation of anti-mycobacterial antibodies. In the future, similar glycoGNPs could be used as components of anti-tuberculosis vaccines.

\section{Experimental \\ Preparation of amino-functionalized $\mathrm{Ara}_{6}$ glycosides 1 and 2}

Glycoside 1 [92,93] with 2-aminoethyl aglycon (Figure 1) was synthesized as described previously [93]. Glycoside 2 [92] with extended amino-functionalized aglycon was synthesized from 2-aminoethyl glycoside 1 by $N$-acylation with $N$-trifluoroacetylated heptaethylene glycol-based amino acid $\mathrm{HO}_{2} \mathrm{CCH}_{2}\left(\mathrm{OCH}_{2} \mathrm{CH}_{2}\right)_{6}$ NHTFA (prepared from 18-crown-6 [114]) in the presence of DMT-MM [115,116] and $N$-methylmorpholine in $\mathrm{MeOH}$ followed by basic deprotection as described previously [92].

\section{Preparation of GNPs and a study of ability of Ara $_{6}$ glycosides 1 and 2 to stabilize nanoparticles}

Gold nanoparticles (GNPs, average diameter $d=15 \mathrm{~nm}$, Figure 2) were prepared by the citrate method of Frens $[67,94]$. For reduction, $0.01 \%$ aqueous tetrachloroauric acid $(242.5 \mathrm{~mL}$, $\mathrm{HAuCl}_{4}$; Sigma-Aldrich) in an Erlenmeyer flask was brought to reflux with stirring on a magnetic stirrer. Then $1 \%$ aqueous sodium citrate $(7.75 \mathrm{~mL}$, Fluka) was added to the flask. Reflux was continued for $30 \mathrm{~min}$ to give a bright red sol that contained GNPs $(d=15 \mathrm{~nm})$ identical to those prepared earlier [77] (hereinafter GNP solution).

The ability of $\mathrm{Ara}_{6}$ glycosides $\mathbf{1}$ and $\mathbf{2}$ to stabilize GNPs in the presence of $\mathrm{NaCl}$ at different $\mathrm{pH}$ values was determined as described below. The $\mathrm{pH}$ value of the GNP solutions was adjusted to $6.2,7.0,8.9,9.7,10.0$, and 10.2 by addition of $0.2 \mathrm{M} \mathrm{K}_{2} \mathrm{CO}_{3}$ aqueous solution. After that, $100 \mu \mathrm{L}$ of an aqueous solution of $\mathrm{Ara}_{6}$ glycoside 1 or 2 (concentration $200 \mu \mathrm{g} \cdot \mathrm{mL}^{-1}$ ) was added to $100 \mu \mathrm{L}$ of the obtained GNP solutions. The mixtures were incubated at room temperature for $10 \mathrm{~min}$. Then $10 \%$ aqueous solution of $\mathrm{NaCl}$ was added to an end concentration of $0.9 \%(\mathrm{~m} / \mathrm{v})$ in each solution. The spectra of the obtained solutions were registered with a Tecan Spark 10M microplate reader (Tecan, Austria) at 400-800 nm (Figure 3).

To prepare glyco-GNPs, the "gold number" (minimal amount of carbohydrate antigen that protects the sol against aggregation induced by $\mathrm{NaCl}$ ) for the glycoside solutions was first determined. To this end, $20 \mu \mathrm{L}$ of aqueous solutions of Ara 6 glycoside 1 or 2 (initial concentration $1 \mathrm{mg} \cdot \mathrm{mL}^{-1}$ ) was titrated twice on a 96-well microtiter plate. Each well received $200 \mu \mathrm{L}$ of GNP solution ( $\mathrm{pH} 9.7$ ) and $20 \mu \mathrm{L}$ of $1.7 \mathrm{M} \mathrm{NaCl}$ aqueous solution. The minimal stabilizing concentration of a glycoside was established visually by the change of color of the GNP solution from red to blue in the wells of a microtiter plate. The minimal stabilizing concentrations for both glycosides were found to be 
$100 \mu \mathrm{g} \cdot \mathrm{mL}^{-1}$. This concentration was used to conjugate antigens 1 and $\mathbf{2}$ with GNPs.

Conjugation was done by simply mixing the components: $4.5 \mathrm{~mL}$ of GNP solution $(d=15 \mathrm{~nm})$ were mixed with $125 \mu \mathrm{L}$ of $0.2 \mathrm{M} \mathrm{K}_{2} \mathrm{CO}_{3}$ aqueous solution (the $\mathrm{pH}$ value of the resulting solution was ca. 9.7) and $0.5 \mathrm{~mL}$ of aqueous solution $\left(1 \mathrm{mg} \cdot \mathrm{mL}^{-1}\right)$ of $\mathrm{Ara}_{6}$ glycoside 1 or 2 was added while stirring to give solutions of $\mathrm{Ara}_{6}$-GNP 3 and $\mathbf{4}$ (containing $100 \mu \mathrm{g} \cdot \mathrm{mL}^{-1}$ of glycosides $\mathbf{1}$ and $\mathbf{2}$, respectively), which were used for immunization. The samples of these mixtures used for spectra recording additionally contained $0.9 \% \mathrm{NaCl}$ (Figure 4(2)).

An estimation of the glycoside content in glyco-GNPs $\mathbf{3}$ and $\mathbf{4}$ by colorimetric determination of carbohydrates using the phenol-sulfuric acid reaction [117] (as described below) suggested that there are no more than 100 glycoside molecules on each nanoparticle on average. The samples of glyco-GNPs 3 and 4 , prepared as described above, were purified from the excess of Ara 6 glycosides 1 and $\mathbf{2}$ by centrifugation (12400g, $30 \mathrm{~min}$, Microspin 12 centrifuge (Biosan, Latvia)), and the precipitate obtained was then re-suspended in a volume of water equal to the volume of the starting dispersion of glyco-GNPs. A $0.5 \mathrm{~mL}$ sample of this aqueous solution was successively mixed with $0.5 \mathrm{~mL}$ of a $5 \%$ aqueous phenol solution in a $10 \mathrm{~mL}$ conical test tube. Next, $2.5 \mathrm{~mL}$ of $95 \%$ sulfuric acid was added to achieve complete mixing of the test tube contents. The solution was allowed to cool by incubation at room temperature for $15 \mathrm{~min}$. Absorbance was measured in $1 \mathrm{~cm}$ quartz cuvettes on a Specord 250 spectrophotometer (Analytik, Jena, Germany) at $490 \mathrm{~nm}$ using solutions of the parent glycoside $\mathbf{1}$ for calibration. The calculation also took into consideration that $1 \mathrm{~mL}$ of GNPs dispersion contains ca. $1.6 \times 10^{12}$ particles and molecular weights of glycosides $\mathbf{1}$ and 2 are $853 \mathrm{~g} \cdot \mathrm{mol}^{-1}$ and $1174 \mathrm{~g} \cdot \mathrm{mol}^{-1}$, respectively.

Stability of the glyco-GNPs $\mathbf{3}$ and $\mathbf{4}$ (prepared as described above) against aggregation was demonstrated by the following experiments. Solutions of glyco-GNPs 3 and $\mathbf{4}$ containing $100 \mu \mathrm{g} \cdot \mathrm{mL}^{-1}$ Ara $_{6}$ glycosides $\mathbf{1}$ and $\mathbf{2}$ (for the spectra, see Figure 4(2)), were centrifuged for $30 \mathrm{~min}$ at $12400 \mathrm{~g}$ on a Microspin 12 centrifuge (Biosan, Latvia) and the precipitate was resuspended in water to give solutions of glyco-GNPs with spectra (Figure 4(3)) virtually identical to the those of starting solutions of glyco-GNPs 3 and 4 (Figure 4(2)) and very similar to that of the starting GNPs (Figure 4(1)). Alternatively, the precipitate of glyco-GNPs $\mathbf{3}$ and $\mathbf{4}$ purified from the excess of Ara $_{6}$ glycosides 1 and $\mathbf{2}$ by centrifugation (see above) was dissolved in 5\% sucrose solution, lyophilized and then the residue was resuspended in $0.9 \% \mathrm{NaCl}$ to give solutions of glyco-GNPs with spectra (Figure 4(4)) virtually identical to the those of starting solutions of glyco-GNPs 3 and $\mathbf{4}$ (Figure 4(2)) and very similar to that of the starting GNPs (Figure 4(1)).

\section{Transmission electron microscopy}

Glyco-GNPs 3 and $\mathbf{4}$ were characterized using a Libra 120 transmission electron microscope (Carl Zeiss, Germany) at $120 \mathrm{kV}$ accelerating voltage at the "Simbioz" Center for the Collective Use of the Research Equipment in the Field of Physical-Chemical Biology and Nanobiotechnology at the Institute of Biochemistry and Physiology of Plants and Microorganisms of the Russian Academy of Sciences (IBPPM RAS). Approximately $20 \mu \mathrm{L}$ of glyco-GNPs suspension was applied to a film (Parafilm, USA) and a formvar-coated copper grid (200 mesh) was placed on the drop for $20 \mathrm{~min}$. Thermal attachment was obtained through holding the grid near an incandescent lamp for $2 \mathrm{~min}$. The excess of the liquids was removed by touching the grid to a strip of the filter paper. The grid was washed by a drop of deionized water, dried and then analyzed by TEM. According to TEM data, the prepared Ara $_{6}$-GNPs 3 and $\mathbf{4}$ had the same size $(d=15 \mathrm{~nm})$ as the parent GNPs (Figure 2).

\section{Animal immunization and obtaining antisera}

Rabbits were immunized with the Ara ${ }_{6}$-GNPs 3 and 4 (one animal for each type of glyco-GNPs) as follows: $0.5 \mathrm{~mL}$ of solutions of Ara $_{6}$-GNP 3 and 4 were mixed with $0.5 \mathrm{~mL}$ of complete Freund's adjuvant (CFA, Sigma, USA). Polyclonal antibodies were raised by subcutaneous immunization of chinchilla rabbits with the solutions of glyco-GNPs $\mathbf{3}$ and $\mathbf{4}$ at 10 points along the spinal column, by giving four injections with an interval of 14 days between them. The obtained sera were tested for interaction with the glycosides $\mathbf{1}$ and $\mathbf{2}$ by dot assay (Figure 5) and with the mycobacterial cells by ELISA (Figure 6, Supporting Information File 1, Figure S1).

Animal care and handling were in accordance with the Guide for the Care and Use of Laboratory Animals, the European Convention for the Protection of Vertebrate Animals Used for Experimental and Other Scientific Purposes, and the legislation of the Russian Federation. The use of the animals was also approved by the institution where the experiments were performed.

\section{Dot assay}

The specificity of the obtained antisera to both Ara $_{6}$ glycosides $\mathbf{1}$ and $\mathbf{2}$ was tested by the dot immunoassay (titrated twice in the microtiter plate) as follows. An aliquot $(1 \mu \mathrm{L})$ of solution of each antigen ( 1 or 2 ) in the double dilutions (initial concentration, $1 \mathrm{mg} \cdot \mathrm{mL}^{-1}$ ) was spotted onto a Westran $\mathrm{S}$ polyvinylidene fluoride (PVDF) membrane (Whatman), and the membrane was 
incubated in a dry-air thermostat at $60{ }^{\circ} \mathrm{C}$ for $15 \mathrm{~min}$. After spotting and drying, the membrane was then blocked for $12 \mathrm{~h}$ with $2 \%$ powdered milk diluted in $10 \mathrm{mM}$ PBS. This procedure was performed to prevent a nonspecific antibody adsorption. Then the membrane was incubated in the obtained rabbit antisera, diluted 1:50 with 0.01 M PBS, at room temperature overnight. The membrane was washed four times at $15 \mathrm{~min}$ intervals with PBS containing $0.02 \%$ Tween 20 . Then, it was incubated in a solution of peroxidase-conjugated AffiniPure Goat Anti-Rabbit IgG (H+L) (Jackson ImmunoResearch Laboratories; diluted 1:2000) in PBS containing 0.02\% Tween 20 and $0.02 \%$ powdered milk for $90 \mathrm{~min}$. The membrane was washed four times for 15 min with PBS containing $0.02 \%$ Tween 20. After that, the membrane was treated with a substrate mixture of $0.05 \% 3,3^{\prime}$-diaminobenzidine and $0.02 \%$ hydrogen peroxide in $0.15 \mathrm{M}$ PBS until intense brown dots appeared (Figure 5).

\section{Bacterial cultures and growth conditions}

Bacterial cultures of M. bovis (vaccine strain BCG), M. phlei, and $M$. smegmatis were obtained from the collection of pathogenic and vaccine microorganisms of animals of Kovalenko Institute of Experimental Veterinary Medicine (Moscow, Russia) [118]. A culture of E. coli strain K-12 was obtained from the Collection of the Rhizosphere Microorganisms of the Institute of Biochemistry and Physiology of Plants and Microorganisms RAS (Saratov, Russia) [119]. The cells were grown on a solid nutrient medium for isolation of Mycobacteria (the Löwenstein-Jensen medium) at $37{ }^{\circ} \mathrm{C}$ for 25 days.

\section{Enzyme-linked immunosorbent assay}

Detection of serological reactions of antisera with mycobacterial cells was carried out by ELISA in 96-well polystyrene plates using the standard procedure, as previously described [120]. Aliquots $(50 \mu \mathrm{L})$ of each bacterial suspension in twofold dilutions (initial concentration, $10^{8}$ cells $\cdot \mathrm{mL}^{-1}$ ) were immobilized in the wells through simple adsorption, kept for $30 \mathrm{~min}$ on a shaker at room temperature. The samples were replaced with $100 \mu \mathrm{L}$ of $0.05 \%$ polyethylene glycol 20000 (PEG), added to each well to block the free binding sites on polystyrene. This solution was replaced with $50 \mu \mathrm{L}$ of primary antibodies (antisera to glyco-GNPs, or intact serum, or antiserum to LPS of Azospirillum brasilense Sp7 [99] as negative control) diluted 1:100 in PBS containing 0.02\% Tween 20 and $0.005 \%$ PEG (for prevention of nonspecific antibody sorption). After incubation for 40-60 min, the wells were washed three times with $100 \mu \mathrm{L}$ of PBS containing $0.02 \%$ Tween 20 , and $50 \mu \mathrm{L}$ of peroxidase-conjugated AffiniPure Goat Anti-Rabbit IgG $(\mathrm{H}+\mathrm{L})$ (Jackson ImmunnoResearch Laboratories, USA; diluted 1:2000) in PBS containing 0.02\% Tween 20 and $0.005 \%$ PEG was placed in each well. After $30 \mathrm{~min}$ incubation, the wells were washed twice with $100 \mu \mathrm{L}$ of PBS containing $0.02 \%$ Tween 20 , and peroxidase activity was estimated by adding to each well $50 \mu \mathrm{L}$ of a substrate mixture of $0.03 \% o$-phenylenediamine and $0.02 \%$ hydrogen peroxide in $0.1 \mathrm{M}$ sodium citrate buffer ( $\mathrm{pH} 4.5$ ). The enzyme reaction was stopped with $100 \mu \mathrm{L}$ of $1 \mathrm{~N} \mathrm{H}_{2} \mathrm{SO}_{4}$. The absorbance at $492 \mathrm{~nm}$ was read on a Multiskan Ascent analyzer (Thermo). Absorbance values at $492 \mathrm{~nm}$ for the wells without bacterial cells were using as the control. Data were processed with Microsoft Excel 2003 software (Microsoft Corp.); 95\% confidence intervals are given (Figure 6, Supporting Information File 1, Figure S1).

\section{Supporting Information}

\section{Supporting Information File 1}

Results of ELISA of M. bovis, M. phlei, M. smegmatis and

E. coli cell suspensions.

[https://www.beilstein-journals.org/bjnano/content/ supplementary/2190-4286-11-39-S1.pdf]

\section{Funding}

This study was carried out under research theme no. AAAAA17-117102740097-1. The work was in part supported by the Russian Science Foundation: no. 19-14-00077 to LD (synthesis of glyco-GNPs and generation of antibodies) and no. 16-1310244-P to LK (synthesis of glycosides, design and analysis of the influence of aglycons).

\section{ORCID ${ }^{\circledR}$ iDs}

Gennady L. Burygin - https://orcid.org/0000-0001-8031-9641 Leonid O. Kononov - https://orcid.org/0000-0003-1858-7738 Lev A. Dykman - https://orcid.org/0000-0003-2440-6761

\section{Preprint}

A non-peer-reviewed version of this article has been previously published as a preprint doi:10.3762/bxiv.2019.155.v1

\section{References}

1. Knirel, Y. A.; Valvano, M. A., Eds. Bacterial lipopolysaccharides: structure, chemical synthesis, biogenesis and interaction with host cells; Springer Vienna: Vienna, Austria, 2011. doi:10.1007/978-3-7091-0733-1

2. Varki, A.; Cummings, R. D.; Esko, J. D.; Stanley, P.; Hart, G. W.; Aebi, M.; Darvill, A. G.; Kinoshita, T.; Packer, N. H.; Prestegard, J. H.; Schnaar, R. L.; Seeberger, P. H., Eds. Essentials of glycobiology, 3rd ed.; Cold Spring Harbor Laboratory Press: Cold Spring Harbor, New York, USA, 2017.

Available from: https://www.ncbi.nlm.nih.gov/books/NBK310274 (accessed Dec 8, 2019).

3. Schloter, M.; Aßmus, B.; Hartmann, A. Biotechnol. Adv. 1995, 13, 75-90. doi:10.1016/0734-9750(94)00023-6 
4. Chen, M.; Shpirt, A. M.; Guo, X.; Shashkov, A. S.; Zhuang, Y.; Wang, L.; Knirel, Y. A.; Liu, B. Microbiology (London, U. K.) 2015, 161, 1790-1796. doi:10.1099/mic.0.000136

5. Mistou, M.-Y.; Sutcliffe, I. C.; van Sorge, N. M. FEMS Microbiol. Rev. 2016, 40, 464-479. doi:10.1093/femsre/fuw006

6. Roy, R., Ed. Carbohydrate-Based Vaccines; ACS Symposium Series, Vol. 989; American Chemical Society: Washington, DC, U.S.A., 2008. doi:10.1021/bk-2008-0989

7. Kim, H.-S.; Ng, E. S. M.; Zheng, R. B.; Whittal, R. M.; Schriemer, D. C.; Lowary, T. L. Studies toward the development of anti-tuberculosis vaccines based on mycobacterial lipoarabinomannan. In Carbohydrate-Based Vaccines; Roy, R., Ed.; ACS Symposium Series, Vol. 989; American Chemical Society: Washington, DC, U.S.A., 2008; pp 184-198. doi:10.1021/bk-2008-0989.ch009

8. Buskas, T.; Thompson, P.; Boons, G.-J. Chem. Commun. 2009, 5335-5349. doi:10.1039/b908664c

9. Guo, Z.; Wang, Q. Curr. Opin. Chem. Biol. 2009, 13, 608-617. doi:10.1016/j.cbpa.2009.08.010

10. Tam, P.-H.; Lowary, T. L. Mycobacterial lipoarabinomannan fragments as haptens for potential anti-tuberculosis vaccines. In Carbohydrate Chemistry; Rauter, A. P.; Lindhorst, T. K., Eds.; Royal Society of Chemistry: Cambridge, U.K., 2010; Vol. 36, pp 38-63. doi:10.1039/9781849730891-00038

11. Wang, Q.; Guo, Z. Carbohydrate Vaccines. In Comprehensive Natural Products II; Mander, L.; Liu, H. W., Eds.; Elsevier: Amsterdam, Netherlands, 2010; pp 91-122. doi:10.1016/b978-008045382-8.00122-2

12. Wang, Q.; Guo, Z. ACS Med. Chem. Lett. 2011, 2, 373-378. doi:10.1021/ml100313d

13. Yu, S.; Wang, Q.; Zhang, J.; Wu, Q.; Guo, Z. Med. Chem. Commun. 2011, 2, 524-530. doi:10.1039/c1md00033k

14. Wang, Q.; Zhou, Z.; Tang, S.; Guo, Z. ACS Chem. Biol. 2012, 7, 235-240. doi:10.1021/cb200358r

15. Peri, F. Chem. Soc. Rev. 2013, 42, 4543-4556. doi:10.1039/c2cs35422e

16. Valdés Balbin, Y.; Rodríguez, M. C.; Verez Bencomo, V. Chapter 26. Antibacterial and antifungal vaccines based on synthetic oligosaccharides. In Carbohydrate Chemistry; Rauter, A. P.; Lindhorst, T. K.; Queneau, Y., Eds.; Royal Society of Chemistry: Cambridge, U.K., 2014; Vol. 40, pp 564-595. doi:10.1039/9781849739986-00564

17. Bhatia, S.; Dimde, M.; Haag, R. Med. Chem. Commun. 2014, 5, 862-878. doi:10.1039/c4md00143e

18. Zhou, Z.; Mondal, M.; Liao, G.; Guo, Z. Org. Biomol. Chem. 2014, 12, 3238-3245. doi:10.1039/c4ob00390j

19. Wang, L.; Feng, S.; An, L.; Gu, G.; Guo, Z. J. Org. Chem. 2015, 80, 10060-10075. doi:10.1021/acs.joc.5b01686

20. Zhou, Z.; Liao, G.; Mandal, S. S.; Suryawanshi, S.; Guo, Z. Chem. Sci. 2015, 6, 7112-7121. doi:10.1039/c5sc01402f

21. Liao, G.; Zhou, Z.; Suryawanshi, S.; Mondal, M. A.; Guo, Z. ACS Cent. Sci. 2016, 2, 210-218. doi:10.1021/acscentsci.5b00364

22. Zhou, Z.; Mandal, S. S.; Liao, G.; Guo, J.; Guo, Z. Sci. Rep. 2017, 7, 11403. doi:10.1038/s41598-017-11500-w

23. Wang, L.; Feng, S.; Wang, S.; Li, H.; Guo, Z.; Gu, G. J. Org. Chem. 2017, 82, 12085-12096. doi:10.1021/acs.joc.7b01817

24. Daniel, M.-C.; Astruc, D. Chem. Rev. 2004, 104, 293-346. doi:10.1021/cr030698+

25. Dykman, L.; Khlebtsov, N. Chem. Soc. Rev. 2012, 41, 2256-2282. doi:10.1039/c1cs15166e
26. Sapsford, K. E.; Algar, W. R.; Berti, L.; Gemmill, K. B.; Casey, B. J.; Oh, E.; Stewart, M. H.; Medintz, I. L. Chem. Rev. 2013, 113, 1904-2074. doi:10.1021/cr300143v

27. Barrientos, Á. G.; de la Fuente, J. M.; Rojas, T. C.; Fernandez, A.; Penades, S. Chem. - Eur. J. 2003, 9, 1909-1921. doi:10.1002/chem.200204544

28. Rojo, J.; Díaz, V.; de la Fuente, J. M.; Segura, I.; Barrientos, A. G.; Riese, H. H.; Bernad, A.; Penadés, S. ChemBioChem 2004, 5 , 291-297. doi:10.1002/cbic.200300726

29. de la Fuente, J. M.; Penadés, S. Biochim. Biophys. Acta, Gen. Subj. 2006, 1760, 636-651. doi:10.1016/j.bbagen.2005.12.001

30. Ojeda, R.; de Paz, J. L.; Barrientos, A. G.; Martín-Lomas, M.; Penadés, S. Carbohydr. Res. 2007, 342, 448-459. doi:10.1016/j.carres.2006.11.018

31. García, I.; Marradi, M.; Penadés, S. Nanomedicine (London, U. K.) 2010, 5, 777-792. doi:10.2217/nnm.10.48

32. Marradi, M.; Martin-Lomas, M.; Penades, S. Glyconanoparticles: polyvalent tools to study carbohydrate-based interactions. In Advances in Carbohydrate Chemistry and Biochemistry; Horton, D., Ed.; Academic Press, 2010; Vol. 64, pp 211-290. doi:10.1016/s0065-2318(10)64005-x

33. Safari, D.; Marradi, M.; Chiodo, F.; Dekker, H. A. T.; Shan, Y.; Adamo, R.; Oscarson, S.; Rijkers, G. T.; Lahmann, M.; Kamerling, J. P.; Penadés, S.; Snippe, H. Nanomedicine (London, U. K.) 2012, 7, 651-662. doi:10.2217/nnm.11.151

34. Safari, D.; Marradi, M.; Chiodo, F.; Dekker, H. A. T.; Shan, Y.; Adamo, R.; Oscarson, S.; Rijkers, G. T.; Lahmann, M.; Kamerling, J. P.; Penadés, S.; Snippe, $\mathrm{H}$. Nanomedicine (London, U. K.) 2012, 7, 1111-1112. doi:10.2217/nnm.12.85

35. Brinãs, R. P.; Sundgren, A.; Sahoo, P.; Morey, S.; Rittenhouse-Olson, K.; Wilding, G. E.; Deng, W.; Barchi, J. J., Jr. Bioconjugate Chem. 2012, 23, 1513-1523. doi:10.1021/bc200606s

36. Reichardt, N. C.; Martín-Lomas, M.; Penadés, S. Chem. Soc. Rev. 2013, 42, 4358-4376. doi:10.1039/c2cs35427f

37. Parry, A. L.; Clemson, N. A.; Ellis, J.; Bernhard, S. S. R.; Davis, B. G.; Cameron, N. R. J. Am. Chem. Soc. 2013, 135, 9362-9365. doi:10.1021/ja4046857

38. Bernardi, A.; Jiménez-Barbero, J.; Casnati, A.; De Castro, C.; Darbre, T.; Fieschi, F.; Finne, J.; Funken, H.; Jaeger, K.-E.; Lahmann, M.; Lindhorst, T. K.; Marradi, M.; Messner, P.; Molinaro, A.; Murphy, P. V.; Nativi, C.; Oscarson, S.; Penadés, S.; Peri, F.; Pieters, R. J.; Renaudet, O.; Reymond, J.-L.; Richichi, B.; Rojo, J.; Sansone, F.; Schäffer, C.; Turnbull, W. B.; Velasco-Torrijos, T.; Vidal, S.; Vincent, S.; Wennekes, T.; Zuilhof, H.; Imberty, A. Chem. Soc. Rev. 2013, 42, 4709-4727. doi:10.1039/c2cs35408j

39. Marradi, M.; Chiodo, F.; García, I.; Penadés, S. Chem. Soc. Rev. 2013, 42, 4728-4745. doi:10.1039/c2cs35420a

40. Reynolds, M.; Marradi, M.; Imberty, A.; Penadés, S.; Pérez, S. Glycoconjugate J. 2013, 30, 747-757. doi:10.1007/s10719-013-9478-6

41. Adak, A. K.; Li, B.-Y.; Lin, C.-C. Carbohydr. Res. 2015, 405, 2-12. doi:10.1016/j.carres.2014.07.026

42. Gregory, A. E.; Judy, B. M.; Qazi, O.; Blumentritt, C. A.; Brown, K. A.; Shaw, A. M.; Torres, A. G.; Titball, R. W. Nanomedicine (N. Y., NY, U. S.) 2015, 11, 447-456. doi:10.1016/j.nano.2014.08.005

43. Poonthiyil, V.; Golovko, V. B.; Fairbanks, A. J. Org. Biomol. Chem. 2015, 13, 5215-5223. doi:10.1039/c5ob00447k 
44. Poonthiyil, V.; Nagesh, P. T.; Husain, M.; Golovko, V. B.; Fairbanks, A. J. ChemistryOpen 2015, 4, 708-716. doi:10.1002/open.201500109

45. Reichardt, N.-C.; Martín-Lomas, M.; Penadés, S. Chem. Commun. 2016, 52, 13430-13439. doi:10.1039/c6cc04445j

46. Compostella, F.; Pitirollo, O.; Silvestri, A.; Polito, L. Beilstein J. Org. Chem. 2017, 13, 1008-1021. doi:10.3762/bjoc. 13.100

47. Vetro, M.; Safari, D.; Fallarini, S.; Salsabila, K.; Lahmann, M.; Penadés, S.; Lay, L.; Marradi, M.; Compostella, F. Nanomedicine (London, U. K.) 2017, 12, 13-23. doi:10.2217/nnm-2016-0306

48. Poonthiyil, V.; Lindhorst, T. K.; Golovko, V. B.; Fairbanks, A. J. Beilstein J. Org. Chem. 2018, 14, 11-24. doi:10.3762/bjoc.14.2

49. Magnusson, G.; Chernyak, A. Y.; Kihlberg, J.; Kononov, L. O. Synthesis of neoglycoconjugates. In Neoglycoconjugates: preparation and application; Lee, Y. C.; Lee, R. T., Eds.; Academic Press: San Diego, USA, 1994; pp 53-143. doi:10.1016/b978-0-12-440585-1.50006-1

50. Lee, R. T.; Lee, Y. C. Neoglycoproteins. In Glycoproteins II; Montreuil, J.; Vliegenthart, J. F. G.; Schachter, H., Eds.; Elsevier: Amsterdam, The Netherlands, 1997; Vol. 29, pp 601-620. doi:10.1016/s0167-7306(08)60630-4

51. Roy, R. The chemistry of neoglycoconjugates. In Carbohydrate chemistry; Boons, G.-J., Ed.; Blackie Academic and Professional: London, UK, 1998; pp 243-321.

52. Bovin, N. V. Glycoconjugate J. 1998, 15, 431-446. doi:10.1023/a:1006963717646

53. Chabre, Y. M.; Roy, R. Design and creativity in synthesis of multivalent neoglycoconjugatesa. In Advances in Carbohydrate Chemistry and Biochemistry; Horton, D., Ed.; Academic Press, 2010; Vol. 63, pp 165-393. doi:10.1016/s0065-2318(10)63006-5

54. Miura, Y. Polym. J. 2012, 44, 679-689. doi:10.1038/pj.2012.4

55. Solís, D.; Bovin, N. V.; Davis, A. P.; Jiménez-Barbero, J.; Romero, A.; Roy, R.; Smetana, K., Jr.; Gabius, H.-J.

Biochim. Biophys. Acta, Gen. Subj. 2015, 1850, 186-235. doi:10.1016/j.bbagen.2014.03.016

56. Dykman, L. A.; Khlebtsov, N. G. Chem. Sci. 2017, 8, 1719-1735. doi:10.1039/c6sc03631g

57. Dykman, L.; Khlebtsov, N. Gold nanoparticles in biomedical applications; CRC Press: Boca Raton, USA, 2018. doi:10.1201/b22465

58. Salazar-González, J. A.; González-Ortega, O.; Rosales-Mendoza, S. Expert Rev. Vaccines 2015, 14, 1197-1211. doi:10.1586/14760584.2015.1064772

59. World Health Organization. Tuberculosis (TB). https://www.who.int/tb/en (accessed Dec 8, 2019).

60. World Health Organization. Tuberculosis Fact Sheet No. 104. https://www.who.int/en/news-room/fact-sheets/detail/tuberculosis (accessed Dec 8, 2019).

61. Coker, R. J. Trop. Med. Int. Health 2004, 9, 25-40. doi:10.1046/j.1365-3156.2003.01156.x

62. Paolo, W. F., Jr.; Nosanchuk, J. D. Lancet Infect. Dis. 2004, 4 287-293. doi:10.1016/s1473-3099(04)01004-7

63. Davies, P. D. O. Ann. Med. (Abingdon, U. K.) 2003, 35, 235-243. doi:10.1080/07853890310005713

64. Brennan, P. J.; Brosch, R.; Birren, B.; Sobral, B. Tuberculosis 2013, 93, 1-5. doi:10.1016/j.tube.2012.11.013
65. Murase, T.; Zheng, R. B.; Joe, M.; Bai, Y.; Marcus, S. L.; Lowary, T. L.; Ng, K. K. J. Mol. Biol. 2009, 392, 381-392. doi:10.1016/j.jmb.2009.06.074

66. Lowary, T. L. Acc. Chem. Res. 2016, 49, 1379-1388. doi:10.1021/acs.accounts.6b00164

67. Frens, G. Nature (London), Phys. Sci. 1973, 241, 20-22. doi:10.1038/physci241020a0

68. Leff, D. V.; Brandt, L.; Heath, J. R. Langmuir 1996, 12, 4723-4730. doi:10.1021/la960445u

69. de la Llave, E.; Clarenc, R.; Schiffrin, D. J.; Williams, F. J. J. Phys. Chem. C 2014, 118, 468-475. doi:10.1021/jp410086b

70. Cai, H.; Yao, P. Colloids Surf., B 2014, 123, 900-906. doi:10.1016/j.colsurfb.2014.10.042

71. Kulandaisamy, A. J.; Rayappan, J. B. B. J. Nanosci. Nanotechnol. 2018, 18, 5222-5233. doi:10.1166/jnn.2018.15388

72. Selvakannan, P. R.; Mandal, S.; Phadtare, S.; Pasricha, R.; Sastry, M. Langmuir 2003, 19, 3545-3549. doi:10.1021/la026906v

73. Zhong, Z.; Patskovskyy, S.; Bouvrette, P.; Luong, J. H. T.; Gedanken, A. J. Phys. Chem. B 2004, 108, 4046-4052. doi:10.1021/jp037056a

74. Porta, F.; Krpetic, Z.; Prati, L.; Gaiassi, A.; Scari, G. Langmuir 2008, 24, 7061-7064. doi:10.1021/la8008392

75. Aghdam, A. G.; Vossoughi, M.; Almzadeh, I.; Zeinali, M. J. Dispersion Sci. Technol. 2008, 29, 1062-1065. doi:10.1080/01932690701815762

76. Hamaguchi, K.; Kawasaki, H.; Arakawa, R. Colloids Surf., A 2010, 367, 167-173. doi:10.1016/j.colsurfa.2010.07.006

77. Dykman, L. A.; Staroverov, S. A.; Mezhenny, P. V.; Fomin, A. S.; Kozlov, S. V.; Volkov, A. A.; Laskavy, V. N.; Shchyogolev, S. Y. Gold Bull. 2015, 48, 93-101. doi:10.1007/s13404-015-0165-1

78. Titanova, E. O.; Burygin, G. L. Proc. SPIE 2015, 9917, $99171 \mathrm{E}$. doi:10.1117/12.2229825

79. Morrow, B. J.; Matijević, E.; Goia, D. V. J. Colloid Interface Sci. 2009, 335, 62-69. doi:10.1016/j.jcis.2009.02.053

80. Simeonova, S.; Georgiev, P.; Exner, K. S.; Mihaylov, L.; Nihtianova, D.; Koynov, K.; Balashev, K. Colloids Surf., A 2018, 557, 106-115. doi:10.1016/j.colsurfa.2018.02.045

81. Chen, F.; Li, X.; Hihath, J.; Huang, Z.; Tao, N. J. Am. Chem. Soc. 2006, 128, 15874-15881. doi:10.1021/ja065864k

82. Yochelis, S.; Katzir, E.; Kalcheim, Y.; Gutkin, V.; Millo, O.; Paltiel, Y. J. Nanotechnol. 2012, 903761. doi:10.1155/2012/903761

83. Lee, S. H.; Bae, K. H.; Kim, S. H.; Lee, K. R.; Park, T. G. Int. J. Pharm. 2008, 364, 94-101. doi:10.1016/j.jpharm.2008.07.027

84. Cecioni, S.; Praly, J.-P.; Matthews, S. E.; Wimmerová, M.; Imberty, A.; Vidal, S. Chem. - Eur. J. 2012, 18, 6250-6263. doi:10.1002/chem.201200010

85. Cecioni, S.; Imberty, A.; Vidal, S. Chem. Rev. 2015, 115, 525-561. doi:10.1021/cr500303t

86. Ligeour, C.; Dupin, L.; Angeli, A.; Vergoten, G.; Vidal, S.; Meyer, A.; Souteyrand, E.; Vasseur, J.-J.; Chevolot, Y.; Morvan, F. Org. Biomol. Chem. 2015, 13, 11244-11254. doi:10.1039/c5ob01445j

87. Wang, S.; Dupin, L.; Noël, M.; Carroux, C. J.; Renaud, L.; Géhin, T.; Meyer, A.; Souteyrand, E.; Vasseur, J.-J.; Vergoten, G.; Chevolot, Y.; Morvan, F.; Vidal, S. Chem. - Eur. J. 2016, 22, 11785-11794. doi:10.1002/chem.201602047

88. Angeli, A.; Li, M.; Dupin, L.; Vergoten, G.; Noël, M.; Madaoui, M.; Wang, S.; Meyer, A.; Géhin, T.; Vidal, S.; Vasseur, J.-J.; Chevolot, Y.; Morvan, F. ChemBioChem 2017, 18, 1036-1047. doi:10.1002/cbic.201700154 
89. Angeli, A.; Dupin, L.; Madaoui, M.; Li, M.; Vergoten, G.; Wang, S.; Meyer, A.; Géhin, T.; Vidal, S.; Vasseur, J.-J.; Chevolot, Y.; Morvan, F. ChemistrySelect 2017, 2, 10420-10427. doi:10.1002/slct.201702131

90. Bagul, R. S.; Hosseini, M.; Shiao, T. C.; Saadeh, N. K.; Roy, R. Polym. Chem. 2017, 8, 5354-5366. doi:10.1039/c7py01044c

91. Svedhem, S.; Öhberg, L.; Borrelli, S.; Valiokas, R.; Andersson, M.; Oscarson, S.; Svensson, S. C. T.; Liedberg, B.; Konradsson, P. Langmuir 2002, 18, 2848-2858. doi:10.1021/la015643m

92. Abronina, P. I.; Podvalnyy, N. M.; Mel'nikova, T. M.; Zinin, A. I.; Fedina, K. G.; Kachala, V. V.; Torgov, V. I.; Kononov, L. O.; Panfertsev, E. A.; Baranova, E. V.; Mochalov, V. V.; Dyatlova, V. I.; Biketov, S. F. Russ. Chem. Bull. 2010, 59, 2333-2337. doi:10.1007/s11172-010-0397-4

93. Podvalnyy, N. M.; Abronina, P. I.; Fedina, K. G.; Kondakov, N. N.; Zinin, A. I.; Chizhov, A. O.; Torgov, V. I.; Kachala, V. V.; Kononov, L. O. Russ. Chem. Bull. 2015, 64, 1149-1162. doi:10.1007/s11172-015-0992-5

94. De Mey, J.; Moeremans, M. The preparation of colloidal gold probes and their use as marker in electron microscopy. In Advanced Techniques in Biological Electron Microscopy III; Koehler, J. K., Ed.; Springer: Berlin, Heidelberg, Germany, 1986; pp 229-271. doi:10.1007/978-3-642-71135-0_6

95. Staroverov, S. A.; Dykman, L. A. Nanotechnol. Russ. 2013, 8, 816-822. doi:10.1134/s1995078013060165

96. Dykman, L. A.; Staroverov, S. A.; Fomin, A. S.; Khanadeev, V. A.; Khlebtsov, B. N.; Bogatyrev, V. A. Int. Immunopharmacol. 2018, 54, 163-168. doi:10.1016/j.intimp.2017.11.008

97. Thiele, H.; Hoppe, K.; Moll, G. Kolloid Z. Z. Polym. 1962, 185, 45-52. doi:10.1007/bf01882348

98. Chow, M. K.; Zukoski, C. F. J. Colloid Interface Sci. 1994, 165 , 97-109. doi:10.1006/jcis.1994.1210

99. Konnova, O. N.; Boiko, A. S.; Burygin, G. L.; Fedonenko, Y. P.; Matora, L. Y.; Konnova, S. A.; Ignatov, V. V. Microbiology (London, U. K.) 2008, 77, 305-312. doi:10.1134/s0026261708030090

100.Bolarinwa, I. F. J. Food Prot. 2015, 78, 1408-1413. doi:10.4315/0362-028x.jpp-15-033

101.Chen, Y.-S.; Hung, Y.-C.; Lin, W.-H.; Huang, G. S. Nanotechnology 2010, 21, 195101. doi:10.1088/0957-4484/21/19/195101

102. Shiosaka, S.; Kiyama, H.; Wanaka, A.; Masaya, T. Brain Res. 1986, 382, 399-403. doi:10.1016/0006-8993(86)91352-1

103.Kim, B.-J.; Lee, S.-H.; Lyu, M.-A.; Kim, S.-J.; Bai, G.-H.; Kim, S.-J.; Chae, G.-T.; Kim, E.-C.; Cha, C.-Y.; Kook, Y.-H. J. Clin. Microbiol. 1999, 37, 1714-1720. doi:10.1128/jcm.37.6.1714-1720.1999

104. Kononov, L. O. RSC Adv. 2015, 5, 46718-46734. doi:10.1039/c4ra17257d

105.Kononov, L. O.; Malysheva, N. N.; Orlova, A. V.; Zinin, A. I.; Laptinskaya, T. V.; Kononova, E. G.; Kolotyrkina, N. G. Eur. J. Org. Chem. 2012, 1926-1934. doi:10.1002/ejoc.201101613

106.Kononov, L. O. Modulation of Stereoselectivity of Glycosylation: A Supramer Approach. In Advances in Chemistry Research; Taylor, J. C., Ed.; Nova Science Publishers: Hauppauge, NY, 2013; Vol. 18, pp 143-178.

107. Abronina, P. I.; Zinin, A. I.; Romashin, D. A.; Tereshina, V. V.; Chizhov, A. O.; Kononov, L. O. Carbohydr. Res. 2018, 464, 28-43. doi:10.1016/j.carres.2018.05.005

108. Podvalnyy, N. M.; Malysheva, N. N.; Panova, M. V.; Zinin, A. I.; Chizhov, A. O.; Orlova, A. V.; Kononov, L. O. Carbohydr. Res. 2017, 451, 12-28. doi:10.1016/j.carres.2017.09.002
109. Orlova, A. V.; Laptinskaya, T. V.; Bovin, N. V.; Kononov, L. O Russ. Chem. Bull. 2017, 66, 2173-2179. doi:10.1007/s11172-017-1999-x

110.Nagornaya, M. O.; Orlova, A. V.; Stepanova, E. V.; Zinin, A. I.; Laptinskaya, T. V.; Kononov, L. O. Carbohydr. Res. 2018, 470, 27-35 doi:10.1016/j.carres.2018.10.001

111. Orlova, A. V.; Andrade, R. R.; da Silva, C. O.; Zinin, A. I.; Kononov, L. O. ChemPhysChem 2014, 15, 195-207. doi:10.1002/cphc.201300894

112. Orlova, A. V.; Tsvetkov, D. E.; Kononov, L. O. Russ. Chem. Bull. 2017, 66, 1712-1715. doi:10.1007/s11172-017-1945-y

113. Fallarini, S.; Paoletti, T.; Battaglini, C. O.; Ronchi, P.; Lay, L.; Bonomi, R.; Jha, S.; Mancin, F.; Scrimin, P.; Lombardi, G. Nanoscale 2013, 5, 390-400. doi:10.1039/c2nr32338a

114. Abronina, P. I.; Zinin, A. I.; Orlova, A. V.; Sedinkin, S. L.; Kononov, L. O. Tetrahedron Lett. 2013, 54, 4533-4535. doi:10.1016/j.tetlet.2013.06.065

115.Kunishima, M.; Kawachi, C.; Hioki, K.; Terao, K.; Tani, S. Tetrahedron 2001, 57, 1551-1558. doi:10.1016/s0040-4020(00)01137-6

116. Kunishima, M.; Hioki, K.; Wada, A.; Kobayashi, H.; Tani, S. Tetrahedron Lett. 2002, 43, 3323-3326. doi:10.1016/s0040-4039(02)00546-4

117.DuBois, M.; Gilles, K. A.; Hamilton, J. K.; Rebers, P. A.; Smith, F. Anal. Chem. (Washington, DC, U. S.) 1956, 28, 350-356. doi:10.1021/ac60111a017

118. Collection of pathogenic and vaccine microorganisms of animals of Kovalenko Institute of Experimental Veterinary (in Russian). https://viev.ru/perechen-obraztsov-hraneniya (accessed Dec 8, 2019).

119. Russian Academy of Sciences. Collection of rhizosphere microorganisms of the Institute of Biochemistry and Physiology of Plants and Microorganisms. https://collection.ibppm.ru (accessed Dec 8, 2019).

120. Yegorenkova, I. V.; Tregubova, K. V.; Matora, L. Y.; Burygin, G. L.; Ignatov, V. V. Curr. Microbiol. 2010, 61, 376-380. doi:10.1007/s00284-010-9622-5

\section{License and Terms}

This is an Open Access article under the terms of the Creative Commons Attribution License (http://creativecommons.org/licenses/by/4.0). Please note that the reuse, redistribution and reproduction in particular requires that the authors and source are credited.

The license is subject to the Beilstein Journal of Nanotechnology terms and conditions: (https://www.beilstein-journals.org/bjnano)

The definitive version of this article is the electronic one which can be found at: doi:10.3762/bjnano.11.39 